\title{
PLESTIODON PARVIAURICULATUS (SQUAMATA: SCINCIDAE)
}

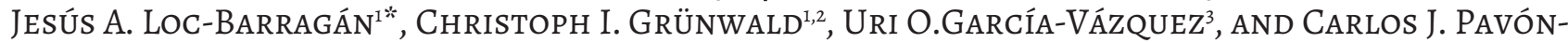
VAZQUEZ ${ }^{4}$

${ }^{1}$ Biodiversa, Comité Nacional para la Conservación de Ecosistemas Mexicanos A.C. Avenida de la Ribera \#203, C.P. 45900, Chapala, Jalisco, México. ${ }^{2}$ Herpetological Conservation International - Mesoamerica Division, 450 Jolina Way, Encinitas, California 92024, United States.

${ }^{3}$ Laboratorio de Sistemática Molecular, Unidad de Investigación Multidisciplinaria de Investigación Experimental Zaragoza, Facultad de Estudios Superiores Zaragoza, Universidad Nacional Autónoma de México, Batalla 5 de Mayo s/n, Col. Ejército de Oriente. 09230, Ciudad de México, México. ${ }^{4}$ Division of Ecology and Evolution, Research School of Biology, Australian National University, Canberra, ACT 2601, Australia.

*Correspondence: biolocbarragan@gmail.com

Mexico: Nayarit: Municipality of El Nayar, on Federal Road 44 (Ruiz, Nayarit-Fresnillo, Zacatecas), $2.3 \mathrm{~km}$ south of the Zacatecas border and $2.5 \mathrm{~km}$ south of the Durango border $\left(22.381564^{\circ} \mathrm{N}\right.$, $104.348159^{\circ} \mathrm{W}$; WGS84; $2244 \mathrm{~m}$ elevation), 30 June 2018. This specimen (Fig. 1) represents the southeasternmost record for the species and the first record from the state of Nayarit, extending the known distribution ca. $458 \mathrm{~km} \mathrm{SW}$ (airline) from the closest known locality, Rancho Madroño, Sierra Surutato, Sinaloa (McDiarmid et al. 1976). The skink was found at 13:30 h, under a piece of dry pine bark in pine-oak forest. The specimen was collected by JALB and CIG, morphologically examined for its identification through scale counts and coloration characters by CJPV and UOGV, and deposited in the Herpetological Collection of the Museo de Zoología, Facultad de Estudios Superiores Zaragoza, Universidad Nacional Autónoma de México (MZFZ 3540).

\section{LITERATURA CITADA}

McDiarmid, R.W., J.F. Copp \& D.E. Breedlove. 1976. Notes on the herpetofauna of western México: new records from Sinaloa and the Tres Marías Islands. Natural History Museum of Los Angeles County, Contributions in Science 275:1-17

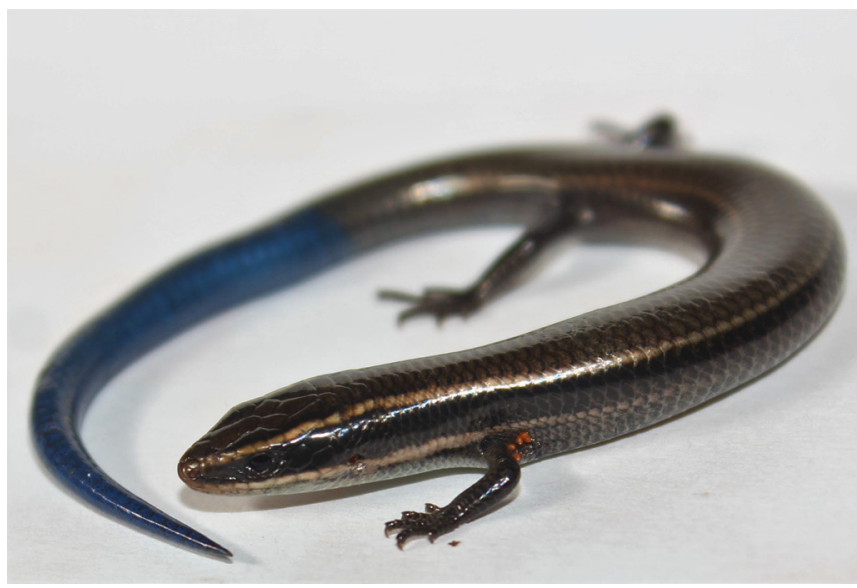

Figura 1. Plestiodon parviauriculatus (MZFZ 3540). Municipio de El Nayar, Nayarit, en la carretera federal 44 (Ruiz, Nayarit-Fresnillo, Zacatecas), $2.3 \mathrm{~km}$ al sur de la frontera de Zacatecas y $2.5 \mathrm{~km}$ al sur de la frontera de Durango, México. Foto por: Jesús A. LocBarragán.

Figure 1. Plestiodon parviauriculatus (MZFZ 3540). Municipality of El Nayar, Nayarit, on Federal Road 44 (Ruiz, Nayarit-Fresnillo, Zacatecas), $2.3 \mathrm{~km}$ south of the Zacatecas border and $2.5 \mathrm{~km}$ south of the Durango border, Mexico. Photo by: Jesús A. Loc-Barragán. 